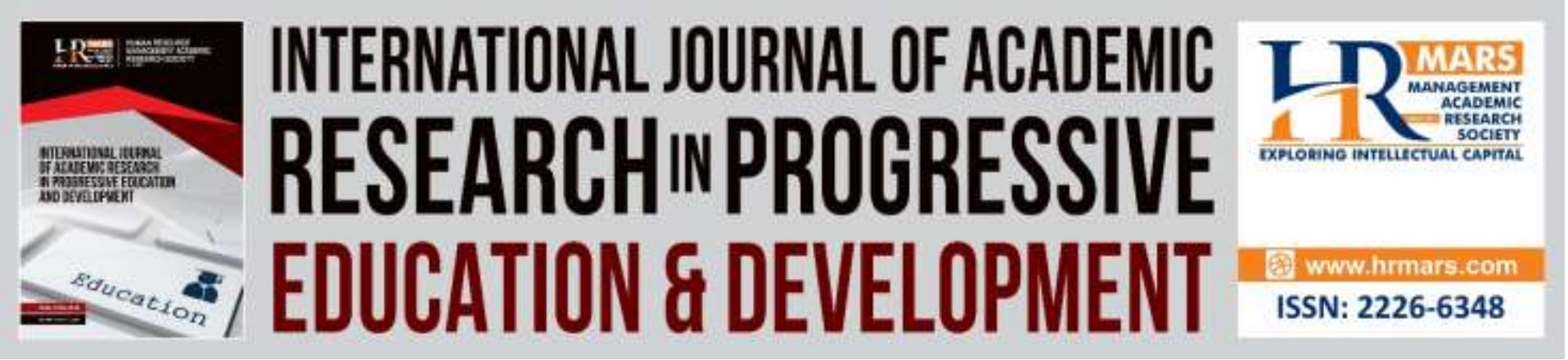

\title{
A Comparison of Curriculum Structure TCSL Teacher Education Programs in Malaysia
}

\section{Afiqah Sabariah binti Khalidar}

To Link this Article: http://dx.doi.org/10.6007/IJARPED/v8-i4/6439

DOI: 10.6007/IJARPED/v8-i4/6439

Received: 25 July 2019, Revised: 18 August 2019, Accepted: 01 September 2019

Published Online: 13 September 2019

In-Text Citation: (Khalidar, 2019)

To Cite this Article: Khalidar, A. S. binti. (2019). A Comparison of Curriculum Structure TCSL Teacher Education Programs in Malaysia. International Journal of Academic Research in Progressive Education and Development, 8(4), 103-115.

\section{Copyright: (C) 2019 The Author(s)}

Published by Human Resource Management Academic Research Society (www.hrmars.com) This article is published under the Creative Commons Attribution (CC BY 4.0) license. Anyone may reproduce, distribute, translate and create derivative works of this article (for both commercial and non-commercial purposes), subject to full attribution to the original publication and authors. The full terms of this license may be seen at: http://creativecommons.org/licences/by/4.0/legalcode

\section{Vol. 8(4) 2019, Pg. 103- 115}

Full Terms \& Conditions of access and use can be found at http://hrmars.com/index.php/pages/detail/publication-ethics 


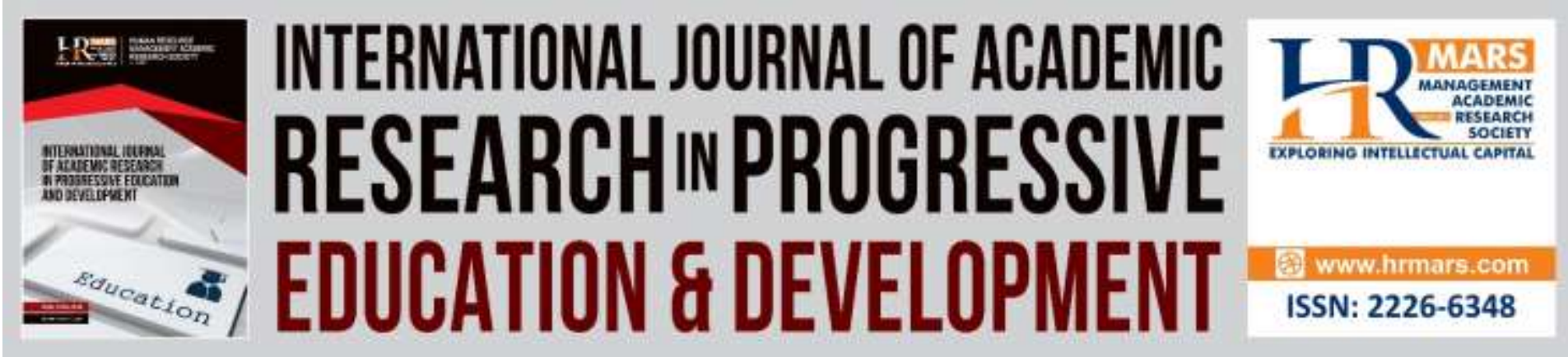

\title{
A Comparison of Curriculum Structure TCSL Teacher Education Programs in Malaysia
}

\author{
Afiqah Sabariah binti Khalidar \\ Lecturer, Modern Language Department, Faculty of Languages and Communication, \\ Sultan Idris Education University, \\ Malaysia.
}

\begin{abstract}
Teacher's education is significant in producing a competent teacher to teach effectively. Thus the design of the curriculum structure is important to prepare prospective teachers to be equipped with the relevant subject matter knowledge and pedagogical skills. This article aims to provide a review and comparison analyses of two teaching Chinese as a second language (TCSL) pre-service teacher education programs. The study identifies the differences and similarities between two TCSL programs namely the Bachelor Degree in Education (Chinese Language Education for Primary School-PISMP-SK) conducted in IPGM (Institute of Teacher Education Malaysia) and Bachelor Degree in Teaching Chinese as a Second Language (TCSLB) which is conducted in Beijing Foreign Studies University, China (BFSU). Documentary study is adopted to identify the similarities and differences in the curriculum structure of PISMP-SK and TCSLB Chinese language programs. Analysis show that both programs consist of core course which are subject related. Both have courses for professional practice and elective core courses. However, the credit hours allocated for core courses component are different for each program, that is $36 \%$ (PISMP-SK) and $84 \%$ (TCSLB) compared to the total credit hours for each program. Meanwhile, for professional practice courses, PISMP-SK has allocated $12 \%$ of the total credit hours, but there is only $1 \%$ for TCSLB. There is a vast difference between these two programs which is there are aspect of compulsory courses in the PISMP-SK program, but not found in TCSLB program. The compulsory courses are the study of Malaysian education philosophy and beliefs, professionalism, knowledge and skills. The study shows that the PISMP-SK curriculum structure has a strong component of pedagogy in teaching Chinese language, Malaysia education philosophy and beliefs and teachers' practice but lack in culture knowledge courses. Meanwhile TCSLB is strong that it strengthens Chinese language proficiencies and culture knowledge but lack in teaching pedagogy and professionalism knowledge. A deeper study to understand the teacher education program in preparing Chinese language teachers is needed to fill up the gap between the 2 programs for a sustainable and effective teacher education.
\end{abstract}

Keywords: Comparison, Curriculum Structure, Teacher Education, Tcsl, Chinese Teachers.

\section{Introduction}

In 2007, the Ministry of Education of Malaysia had implement Chinese as a second language teaching program in thousands of national primary schools across the country. (Ye, 
2012) In 2009, there are about 350 national primary schools started to open Chinese as a second language classes. In 2011, Chinese as a second language was included in the official curriculum of the national primary school. This is to encourage more non-native Chinese speakers' students to learn Chinese language.

These Chinese as a second language classes are elective language classes that students can choose from another 2 additional language subject which are Tamil and Arabic. Students will attend 3 learning hours with a total of 90 minutes per week to learn Chinese as a second language.

Ke (2017); Galdeano, Ahmed, Fati, Rehan, \& Ahmed, (2019) stated due to the demand for Chinese language has increased so the demand for Chinese language teachers has increased in all stages of Malaysia. However, from the information of 2006-2015 for a total of ten years, the problem of the shortage of Chinese language teachers has not been solved.

Because of a shortage Chinese language teacher issue, hence the Ministry of Education Malaysia has identified few Chinese language teacher education programs which conducted in Malaysia and China to cultivate Chinese language teachers continuously.

\section{Teacher Education Curriculum}

Teacher education refers to the policies and procedures designed to equip prospective teachers with the knowledge, attitudes, behaviours and skills they require to perform their tasks effectively in the classroom, school and wider community. Although ideally it should be conceived of, and organized as a seamless continuum, teacher education is often divided into these stages which are below:

a) Initial teacher training/education: A pre-service course before entering the classroom as a fully responsible teacher.

b) Induction: The process of providing training and support during the first few years of teaching or the first year in a particular school.

c) Continuing professional development (CPD): An in-service process for practicing teachers. (Samsujjaman, 2017; Ahmed, Majid, Phulpoto, \& Umrani, (2016).

On top of that, curriculum plays an important role in teacher education program. Comprehensive curriculum structure can produce a competent teacher. Cooper \& Alvarado (2009) stated effective teacher education programs have a solid curriculum that balances content knowledge courses with pedagogy and methods courses especially in programs that are training primary school teachers.

So, it is important for teacher education to have a great curriculum structure because it will help prepare teachers to face teaching and learning environment challenges. Pre-service teacher education not only have to equip their students with subject knowledge content and pedagogy skills, but also have to equip their students with experience and guidance.

\section{Malaysian Chinese Language Teacher Preparation Programs}

In Malaysia, teacher education programs offered by IPGM for preparing teachers for primary schools; public universities such as University Malaya, University Sains Malaysia, University Kebangsaan Malaysia, University Pendidikan Sultan Idris will offer teacher education programs in training teachers for secondary schools. Presently there are few teacher education programs offered in IPGM and public university namely University Pendidikan Sultan Idris only for Chinese language. The general information regarding the related programs is shown in table below: 
INTERNATIONAL JOURNAL OF ACADEMIC RESEARCH IN PROGRESSIVE EDUCATION AND DEVELOPMENT

Vol. 8, No. 4, 2019, E-ISSN: 2226-6348 @ 2019 HRMARS

Table 1. General Information of Chinese Language Teacher Education Undergraduate Programs

\begin{tabular}{|c|c|c|c|c|}
\hline Programs & Duration & Agency & $\begin{array}{l}\text { Placement in } \\
\text { schools }\end{array}$ & $\begin{array}{l}\text { Entry } \\
\text { qualification }\end{array}$ \\
\hline $\begin{array}{l}\text { Bachelor Degree } \\
\text { in Education ( } \\
\text { Chinese } \\
\text { Language } \\
\text { Education for } \\
\text { Primary Chinese } \\
\text { School-SJKC) } \\
\text { (PISMP) }\end{array}$ & 4 years & $\begin{array}{l}\text { Institute of } \\
\text { Teacher } \\
\text { Education, } \\
\text { Malaysia. (IPGM) }\end{array}$ & -primary school & $\begin{array}{l}-5 \text { A in The } \\
\text { Malaysian } \\
\text { Certificate of } \\
\text { Education (SPM) } \\
\text {-with A- in SPM } \\
\text { Chinese Language } \\
\text { result }\end{array}$ \\
\hline $\begin{array}{l}\text { Bachelor Degree } \\
\text { in Education ( } \\
\text { Chinese } \\
\text { Language } \\
\text { Education for } \\
\text { Malay Primary } \\
\text { School-SK) } \\
\text { (PISMP) }\end{array}$ & 4 years & $\begin{array}{l}\text { Institute of } \\
\text { Teacher } \\
\text { Education, } \\
\text { Malaysia. (IPGM) }\end{array}$ & -primary school & $\begin{array}{l}-5 \text { A in The } \\
\text { Malaysian } \\
\text { Certificate of } \\
\text { Education (SPM) } \\
\text {-with A- in SPM } \\
\text { Chinese Language } \\
\text { result }\end{array}$ \\
\hline $\begin{array}{l}\text { Diploma of } \\
\text { education for } \\
\text { post graduate } \\
\text { (DPLI) }\end{array}$ & 9 months & $\begin{array}{l}\text { Institute of } \\
\text { Teacher } \\
\text { Education, } \\
\text { Malaysia. (IPGM) }\end{array}$ & $\begin{array}{l}\text {-primary school, - } \\
\text { secondary or } \\
\text { colleges(TVET, } \\
\text { boarding schools, } \\
\text { religious schools) }\end{array}$ & $\begin{array}{l}\text { Bachelor degree } \\
\text { in any field }\end{array}$ \\
\hline $\begin{array}{l}\text { Bachelor Degree } \\
\text { with Education ( } \\
\text { Chinese } \\
\text { Language) (ISMP) }\end{array}$ & 4 years & $\begin{array}{l}\text { Univsersity } \\
\text { Pendidikan Sultan } \\
\text { Idris (UPSI) }\end{array}$ & $\begin{array}{l}\text {-Secondary } \\
\text { schoools } \\
\text { - colleges(TVET, } \\
\text { Boarding schools, } \\
\text { religious schools) }\end{array}$ & $\begin{array}{l}\text {-with a minima } \\
\text { NGMP of } 2.00 \text { and } \\
\text { above in } \\
\text { Malaysian Higher } \\
\text { School } \\
\text { Certificate(STPM) } \\
\text {-with B4 in SPM } \\
\text { Chinese Language } \\
\text { result }\end{array}$ \\
\hline
\end{tabular}

For PISMP program in IPGM, the program offered are different for future SJKC Chinese language teachers who are teaching Chinese as a first language; and for future SK Chinese language teachers who are teaching Chinese as a second language. Presently, Institute of Teacher Education Malaysia (IPGM) is focusing in training pre-service teachers for all the primary school throughout Malaysia. They are pre-service Chinese language teacher education undergraduate programs specifically in preparing teachers to teach teaching Chinese as a second language (TCSL), as shown in table 2. TCSLB students are studying in Beijing Foreign Language University, China.

For program in TCSL offered in Malaysia, all students are Malaysian Chinese and already have no problem in communicating or writing in Chinese. But, for TCSL programs that are offered in Beijing, China, they are mainly Malay students and have zero knowledge in Chinese language. 
For a year, they have to attend foundation classes in respective university to learn communicative and writing in Chinese before they start their bachelor degree program. Furthermore, TCSL teachers who graduated from Beijing have to attend one year of educational diploma course in Institute of Teacher Education, Malaysia.

Table 2. Chinese Language Teacher Education Undergraduate Programs

\begin{tabular}{|l|l|l|l|}
\hline Programs & Duration of study & Place of study & Students \\
\hline $\begin{array}{l}\text { Bachelor Degree in } \\
\text { Education ( Chinese } \\
\text { Language Education for } \\
\text { Primary School) (PISMP- } \\
\text { SK) }\end{array}$ & $\begin{array}{l}\text { Institute of Teacher } \\
\text { Education, } \\
\text { Malaysia }\end{array}$ & $\begin{array}{l}\text { Eligible students } \\
\text { who possessed } \\
\text { good grades in } \\
\text { SPM Chinese } \\
\text { language exam. }\end{array}$ \\
\hline $\begin{array}{l}\text { Bachelor Degree in } \\
\text { Teaching Chinese as a } \\
\text { Second Language (TCSLB) }\end{array}$ & 4 years & $\begin{array}{l}\text { Beijing Foreign } \\
\text { Studies University, } \\
\text { China }\end{array}$ & $\begin{array}{l}\text { Malay students } \\
\text { who doesn't } \\
\text { have any } \\
\text { knowledge in } \\
\text { Chinese } \\
\text { language. }\end{array}$ \\
\hline
\end{tabular}

Through these programs, TCSL teachers in Malaysia are prepared for teaching at national primary school, national secondary school, secondary boarding school and vocational college. In addition to the pre-service programs presented above, other modes for teacher development exist. These include in-service training at school, district and state levels to improve skills, knowledge, and competence of teachers to improve their teaching methods and effectiveness to be better in performing their duties as TCSL teachers. 
DEVELOPMENT

Vol. 8, No. 4, 2019, E-ISSN: 2226-6348 @ 2019 HRMARS

\section{Malaysian TCSL Teacher's Curriculum Structure}

When examining the curriculum structures of PISMP-SK and TCSLB programs, there 5 main components found in PISMP-SK, namely compulsory courses, basic education courses, core courses which is subject related, professional practise courses and elective courses; meanwhile, there are only 3 main components in TCSLB program which are core course, elective core courses and professional practise courses, as shown in table 3 below:

Table 3. PISMP-SK and TCSLB Program Curriculum Structure

\begin{tabular}{|c|c|c|c|c|}
\hline Programs & Components & Subjects & Credit Hours & $\begin{array}{ll}\text { Total Credit } \\
\text { Hours }\end{array}$ \\
\hline \multirow{6}{*}{$\begin{array}{l}\text { Bachelor Degree } \\
\text { in Education ( } \\
\text { Chinese } \\
\text { Language } \\
\text { Education for } \\
\text { Primary School) } \\
\text { (PISMP-SK) }\end{array}$} & $\begin{array}{l}\text { Institute of } \\
\text { Teacher } \\
\text { Education } \\
\text { compulsory } \\
\text { courses }\end{array}$ & 6 & 16 & \multirow[t]{6}{*}{133} \\
\hline & $\begin{array}{l}\text { Basic education } \\
\text { courses }\end{array}$ & 8 & 24 & \\
\hline & Core courses & 17 & 48 & \\
\hline & $\begin{array}{l}\text { Professional } \\
\text { practise courses }\end{array}$ & 5 & 16 & \\
\hline & $\begin{array}{l}\text { Elective } \\
\text { courses }\end{array}$ & 7 & 20 & \\
\hline & $\begin{array}{l}\text { Open } \\
\text { courses }\end{array}$ & 3 & 9 & \\
\hline \multirow{3}{*}{$\begin{array}{l}\text { Bachelor Degree } \\
\text { in Teaching } \\
\text { Chinese as a } \\
\text { Second Language } \\
\text { (TCSLB) }\end{array}$} & Core courses & 15 & 126 & \multirow[t]{3}{*}{150} \\
\hline & $\begin{array}{l}\text { Professional } \\
\text { practise courses }\end{array}$ & 1 & 2 & \\
\hline & $\begin{array}{l}\text { Elective } \\
\text { courses }\end{array}$ & 11 & 22 & \\
\hline
\end{tabular}

For PISMP-SK programs, it consists of 46 courses with a total of 133 credit hours. Among the 46 courses, they are 14 compulsory educational courses such as English Language Proficiency, Educator's Characters Building, Ethnic Relations, Malaysia Philosophy and Education, Child Development, Classroom and Behaviour Management. There are 5 professional practise courses which consist of Planning of teaching learning, Practicum 1, Practicum 2, Internship, School-based Experience courses to equip future teachers in authentic school environment. On top of that, there are 17 core courses and 7 elective core courses which are related to Chinese language competency. For these components, they have courses in Chinese literature, Chinese linguistics and Chinese language pedagogy. Details of courses in each component is shown in table 4 below. 
INTERNATIONAL JOURNAL OF ACADEMIC RESEARCH IN PROGRESSIVE EDUCATION AND DEVELOPMENT

Vol. 8, No. 4, 2019, E-ISSN: 2226-6348 C 2019 HRMARS

Table 4. Courses in PISMP-SK Program

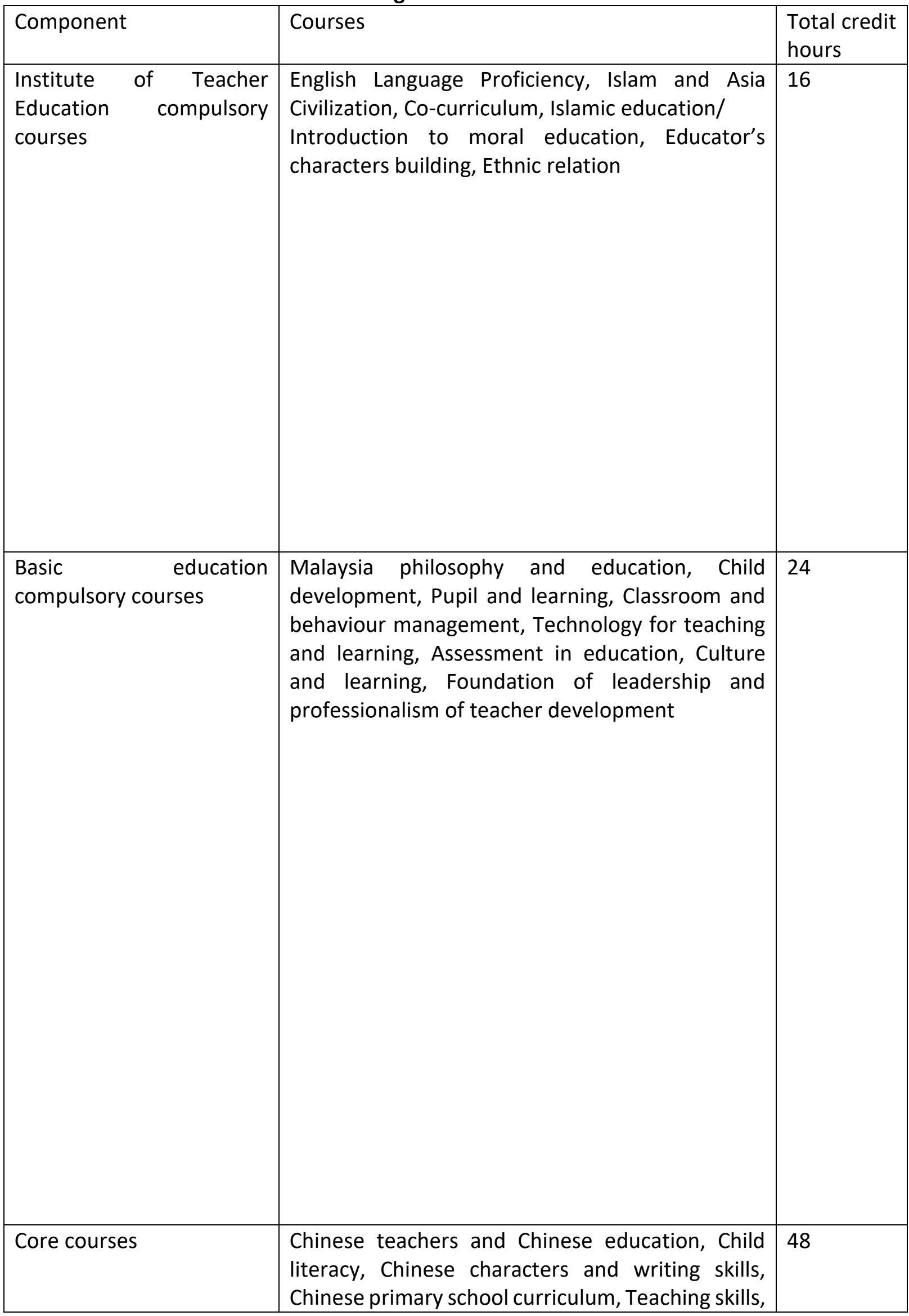




\begin{tabular}{|c|c|c|}
\hline & $\begin{array}{l}\text { Teaching and learning of reading skills, Teaching } \\
\text { and learning of writing skills, Teaching and } \\
\text { learning of speaking skills, Chinese prose, } \\
\text { Managing sources of teaching and learning } \\
\text { Chinese, Chinese poetry, Knowledge of Chinese } \\
\text { linguistics, Inclusive education, Source of } \\
\text { searching in education, Digital innovation in } \\
\text { teaching and learning, Chinese novel and drama, } \\
\text { Research in education -project paper }\end{array}$ & \\
\hline $\begin{array}{l}\text { Professional practise } \\
\text { courses }\end{array}$ & $\begin{array}{l}\text { Planning of teaching learning, Practicum 1, } \\
\text { Practicum 2, Internship, School-based experience }\end{array}$ & 16 \\
\hline Elective core courses & 7 subjects & 20 \\
\hline \multirow[t]{2}{*}{ Open elective courses } & 3 subjects & 9 \\
\hline & Total credit hours & 133 \\
\hline
\end{tabular}

For TCSLB program, it consists of 27 courses with total of 150 credit hours. Among the 27 courses, there are 15 core courses and 11 elective core courses that are all related to the Chinese language skills and content and Chinese culture knowledge. Core courses subjects such as reading comprehension, writing comprehension, speaking comprehension and Chinese comprehension are provided to enhance students' Chinese language skills and content. Elective core courses that students can choose to attend such as social custom and cultures in China, Chinese art, Chinese martial art and cultural diffusion are given to cultivate student's interest and knowledge towards Chinese culture. There are only 1 professional practise course which consists of 2 credit hours of teaching practise. Details of courses for each component are shown in Table 5 below. 
DEVELOPMENT

Vol. 8, No. 4, 2019, E-ISSN: 2226-6348 @ 2019 HRMARS

Table 5. Courses in TCSLB Program

\begin{tabular}{|c|c|c|}
\hline Component & Courses & $\begin{array}{l}\text { Total credit } \\
\text { hours }\end{array}$ \\
\hline Core courses & $\begin{array}{l}\text { Primary reading comprehension, Primary listening } \\
\text { comprehension, Primary spoken chinese, Primary Chinese } \\
\text { comprehensive, Intermediate reading comprehension, } \\
\text { Intermediate listening comprehension and speaking, } \\
\text { Intermediate Chinese comprehensive, Japanese intensive } \\
\text { reading, Chinese writing, Chinese audio-visual comprehension } \\
\text { and speaking, Advanced Chinese comprehensive, Advanced } \\
\text { spoken chinese, Introduction to chinese, Chinese-malay } \\
\text { translation, Thesis writing }\end{array}$ & 126 \\
\hline $\begin{array}{l}\text { Professional } \\
\text { practise } \\
\text { courses }\end{array}$ & Teaching practise & 2 \\
\hline \multirow[t]{2}{*}{$\begin{array}{l}\text { Elective core } \\
\text { courses }\end{array}$} & 11 subjects & 22 \\
\hline & Total credit hours & 150 \\
\hline
\end{tabular}

\section{Comparison of Curriculum Structure between PISMP-SK and TCSLB Programs}

Futrell (2010) stated that the key role of any teacher training program provided by teacher education organizations is to assist students obtain adequate abilities, knowledge, values and attitudes in order to provide their learners with quality teaching experiences.

Table 6. Comparison of Curriculum Structure between PISMP-SK and TCSLB Programs

\begin{tabular}{|c|c|c|c|c|}
\hline \multirow[t]{2}{*}{ Components } & \multicolumn{2}{|c|}{ PISMP-SK } & \multicolumn{2}{|l|}{ TCSLB } \\
\hline & Courses & Credit Hours & Courses & Credit Hours \\
\hline $\begin{array}{l}\text { Institute of Teacher } \\
\text { Education } \\
\text { compulsory courses }\end{array}$ & 6 & 16 & 0 & 0 \\
\hline $\begin{array}{l}\text { Basic education compulsory } \\
\text { courses }\end{array}$ & 8 & 24 & 0 & 0 \\
\hline Core courses & 17 & 48 & 15 & 126 \\
\hline $\begin{array}{c}\text { Professional } \\
\text { courses }\end{array}$ & 5 & 16 & 1 & 2 \\
\hline Elective core courses & 7 & 20 & 11 & 22 \\
\hline Open elective courses & 3 & 9 & 0 & 0 \\
\hline Total & 46 & 133 & 27 & 150 \\
\hline
\end{tabular}

As shown on Table 6, curriculum structure between PISMP-SK and TCSLB programs are being compared on their components, courses and credit hours. This comparison shows that these two programs have their similarities and differences mainly in their curriculum structure components. It is found that some components integrated in PISMP-SK programs are similar to TCSLB programs. Those components are found to be similar on both programs are core courses, professional practise courses and elective core courses. Those similarity can be seen on Table 7 below. 
INTERNATIONAL JOURNAL OF ACADEMIC RESEARCH IN PROGRESSIVE EDUCATION AND

DEVELOPMENT

Vol. 8, No. 4, 2019, E-ISSN: 2226-6348 @ 2019 HRMARS

Table 7. Similarity between PISMP-SK and TCSLB Programs Components

\begin{tabular}{|c|c|c|c|c|c|c|}
\hline \multirow[t]{2}{*}{ Components } & \multicolumn{3}{|c|}{ PISMP-SK } & \multicolumn{3}{|l|}{ TCSLB } \\
\hline & Courses & $\begin{array}{l}\text { Credit } \\
\text { Hours }\end{array}$ & $\begin{array}{l}\text { Credit } \\
\text { Hours } \\
\text { Percentage } \\
\end{array}$ & Courses & $\begin{array}{l}\text { Credit } \\
\text { Hours }\end{array}$ & $\begin{array}{l}\text { Credit } \\
\text { Hours } \\
\text { Percentage }\end{array}$ \\
\hline Core courses & 17 & 48 & $36.09 \%$ & 15 & 126 & $84.00 \%$ \\
\hline $\begin{array}{l}\text { Professional } \\
\text { practise } \\
\text { courses }\end{array}$ & 5 & 16 & $12.03 \%$ & 1 & 2 & $1.33 \%$ \\
\hline $\begin{array}{l}\text { Elective core } \\
\text { courses }\end{array}$ & 7 & 20 & $15.04 \%$ & 11 & 22 & $14.67 \%$ \\
\hline Total & 29 & 84 & $63.16 \%$ & 27 & 150 & $100 \%$ \\
\hline
\end{tabular}

For PISMP-SK core courses, they have 17 courses with total of 48 credit hours. These core courses can be identified mainly on TCSL pedagogy, Chinese literature, linguistics and teaching and learning courses. With 126 credit hours of 15 core courses, TCSLB program's core courses contents are identified to be Chinese language knowledge and skills and linguistics. Those classes such as reading, writing, speaking and Chinese comprehensive classes actually stand 84.00 percent of whole program curriculum structure. But for PISMP-SK program, their core courses only stand 36.09 percent. This huge different of core courses total credit hours percentage show that TCSLB program is emphasizing on their students Chinese language knowledge skills and linguistics development.

Professional practise courses components have been implemented on both programs. Genevieve A. (2017) state that teaching practises is an opportunity for aspiring teachers to understand the role and operation of how the business of schooling is done. It is a field experience where provides a challenging yet rewarding experience of working with students in actual classrooms and acquiring professional competence. That experience actually can enhance the teacher's acquisition of professional competence. For PISMP-SK program, they allocate 20 credit hours of teaching practise instead of only 2 credit hours by TCSLB programs. This shows that PISMP-SK program has been paying attention in equip TCSL teacher to be in a real school working experience. Meanwhile TCSLB program really lack in preparing their students on how to teach and handle students when they become a teacher.

Both programs have elective core courses. Their total credit hours also are not much different between each other. Their only differences are on this component courses contain. For TCSLB program, this component contains Chinese culture courses and Chinese literature but for PISMP-SK program, their elective core courses choices are mostly about pedagogy classes only. 
INTERNATIONAL JOURNAL OF ACADEMIC RESEARCH IN PROGRESSIVE EDUCATION AND DEVELOPMENT

Vol. 8, No. 4, 2019, E-ISSN: 2226-6348 @ 2019 HRMARS

Table 8. Differences between PISMP-SK and TCSLB Programs Components

\begin{tabular}{|c|c|c|c|c|c|c|}
\hline \multirow[t]{2}{*}{ Components } & \multicolumn{3}{|c|}{ PISMP-SK } & \multicolumn{3}{|l|}{ TCSLB } \\
\hline & Courses & $\begin{array}{l}\text { Credit } \\
\text { Hours }\end{array}$ & $\begin{array}{l}\text { Credit } \\
\text { Hours } \\
\text { Percentage }\end{array}$ & Courses & $\begin{array}{l}\text { Credit } \\
\text { Hours }\end{array}$ & $\begin{array}{l}\text { Credit } \\
\text { Hours } \\
\text { Percentage }\end{array}$ \\
\hline $\begin{array}{l}\text { Institute of } \\
\text { Teacher } \\
\text { Education } \\
\text { compulsory } \\
\text { courses }\end{array}$ & 6 & 16 & $12.03 \%$ & 0 & 0 & $0 \%$ \\
\hline $\begin{array}{l}\text { Basic } \\
\text { education } \\
\text { compulsory } \\
\text { courses }\end{array}$ & 8 & 24 & $18.04 \%$ & 0 & 0 & $0 \%$ \\
\hline $\begin{array}{l}\text { Open elective } \\
\text { courses }\end{array}$ & 3 & 9 & $6.77 \%$ & 0 & 0 & $0 \%$ \\
\hline Total & 17 & 49 & $36.84 \%$ & 0 & 0 & $0 \%$ \\
\hline
\end{tabular}

According to Orlando (2013) teachers' attitudes towards their students, their subject taught and their work is very important in their effort of providing challenging and nurturing learning environment. In the light of the above Table 8 PISMP-SK and TCSLB programs components differences, it is found that there are three components integrated in PISMP-SK program's curriculum structure but not found in TCSLB program.

In PISMP-SK program's curriculum structure, it is compulsory for students to attend Institute Teacher Education courses and basic education courses. These two courses are focusing on ensuring future teachers to be aligned with Malaysia education philosophy and beliefs. These two components alone stand about one third of PISMP-SK program's curriculum structure. This is because it is important to promote a competent teacher in Malaysia.

Because of TCSLB program's curriculum structure did not provide those two components as mentioned above, therefore TCSLB graduated students have to attend one year of Postgraduate Education Diploma or known as DPLI program in Malaysia. This is to fill the gap in TCSLB students who are lacking in Malaysia education philosophy and profession related knowledge and skills.

For open elective courses, this component's courses are totally unrelated to the program. It is found that students can choose mathematics, science or even art courses just to equip themselves with new knowledge that they might be interested in.

\section{Conclusion}

TCSL teacher in Malaysia have two different programs and curriculum structures. Both curriculum structures have their own strengths and weaknesses. PISMP-SK program's curriculum structure strengths are in their Malaysia education philosophy and beliefs courses, teaching Chinese pedagogical courses and teaching practise courses. But, their weaknesses are they are lack in providing their students' knowledge of Chinese culture. For TCSLB program's curriculum 
structure, their strengths are in equipping TCSL students on Chinese language's proficiency and Chinese culture. Meanwhile courses related to teaching Chinese pedagogy, teaching practise and Malaysia education philosophy and beliefs are TCSLB programs' weaknesses.

So, it is recommended a deeper study to be conducted to have a better understanding to secure effectiveness and competency of TCSL teachers in Chinese language content, pedagogical skills, teachers' practise, culture knowledge.

\section{Acknowledgment}

This research was fully supported by Sultan Idris Education University (UPSI) Education Grant (code: 2018-0015-107-01) under project named "Investigation of Past and Present Teachers Preparation to Identify Gaps and to Improve Pre-Service Teachers Education". We would like to thank our colleagues and friends who have been such a great help in helping us to collect documents and giving us an insight of TCSL teachers situation in Malaysia.

\section{Corresponding Author}

Lin Chia Ying (Ph.D)

Senior Lecturer, Modern Language Department, Language and Communication Faculty, Sultan Idris Education University, Malaysia.

Email: cylin@fbk.upsi.edu.my

\section{References}

Galdeano, D., Ahmed, U., Fati, M., Rehan, R., \& Ahmed, A. (2019). Financial performance and corporate social responsibility in the banking sector of Bahrain: Can engagement moderate? Management Science Letters, 9(10), 1529-1542.

Ahmed, U., Majid, A. H., Zin, M. L., Phulpoto, W., \& Umrani, W. A. (2016). Role and impact of reward and accountability on training transfer. Business and Economics Journal, $7(1)$. http://dx.doi.org/10.4172/2151-6219.1000195

Brown, H. D. (1994). Principles of language learning and teaching (3rd edn). Englewood Cliffs, NJ:Prentice Hall Regents.

Cooper, J. M., \& Alvarado, A. (2009). Preparation, recruitment, and retention of teachers (Education Policy Series 5). Retrieved from UNESCO website: http://www.iiep.unesco.org/en

Futrell, M. (2010). Transforming Teacher Education to Reform America"s P-20 education system. Journal of Teacher Education, 6(5), 432-440.

Genevieve A. (2017). The Role of Teaching Practice in Teacher Education Programmes: Designing framework for best practice. Global Journal Of Educational Research. 16, 101110.

Ke, W. J. (2017). Malaysian Chinese Education Teacher Development Issues --- Based on The Research Findin0gs of "Overseas Chinese Education Dynamics". Overseas Chinese Education, 86(3), 424-432.

Orlando, M. (2013). Nine Characteristics of a Great Teacher. Teaching strategies for the college classrooms: A collection of faculty articles. Retrieved from www.facultyfocus.com. 
INTERNATIONAL JOURNAL OF ACADEMIC RESEARCH IN PROGRESSIVE EDUCATION AND DEVELOPMENT

Vol. 8, No. 4, 2019, E-ISSN: 2226-6348 @ 2019 HRMARS

Samsujjaman. (2017). Principle and Significance of Teacher Education. International Journal of Engineering Development and Research, 5(2), 1995-1999.

Ye, J. J. (2012). Malaysian Chinese Teaching Research. (Ph.D Thesis). Minzu University of China, Beijing, China. 